\title{
Prevalence of multiple sclerosis in key cities of Brazil: a study in Passo Fundo, Southern Brazil
}

\author{
Prevalência de esclerose múltipla em cidades-chave do Brasil: um estudo em Passo \\ Fundo, no sul do Brasil
}

Giordani Rodrigues DOS PASSOS ${ }^{1}$, Jefferson BECKER', Daniel Lima VARELA², Alan Christmann FRÖHLICH², Bruna Constantino RECH², Ana Carolina Squeff de MATTOS ${ }^{3}$, Dagoberto CALLEGARO4, Marco Aurélio LANAPEIXOTO , on behalf of the Brazilian Committee for Treatment and Research in Multiple Sclerosis

\begin{abstract}
Background: To improve the comparability of multiple sclerosis (MS) prevalence across Brazilian regions, the Brazilian Committee for Treatment and Research in MS has implemented a standardized approach to assess the prevalence of the disease in five key cities, which were deemed representative of their regions in terms of socio-geographical features and where in-person revision of each case was feasible. Objective: To report the point-prevalence of MS in Passo Fundo, one of the key cities in Southern Brazil. Methods: We sought to identify all MS patients who were living in Passo Fundo on July $1^{\text {st }}, 2015$. The primary source for case ascertainment was records from the offices of neurologists and neurosurgeons practicing in the city. Multiple secondary sources were used to maximize identification of cases. All patients underwent in-person review of the diagnosis by a panel of neurologists with experience in MS. Results: We identified 52 MS patients living in Passo Fundo on July 1 st $^{2}$ 2015. The point-prevalence rate for MS was 26.4/100,000 population (95\% confidence interval, 19.7 to 34.6/100,000). Among the MS cases, 42 (80.8\%) were female, for a sex ratio of 4.2:1. Forty-six cases (88.5\%) were categorized as relapsing-remitting MS, and the remaining 6 cases, as secondary progressive MS (11.5\%). Other epidemiological and clinical features were comparable to national and international MS populations. Conclusions: The prevalence of MS in Passo Fundo is one of the highest reported in Brazil so far. Studies in other key Brazilian cities, using the same methodology, are currently being carried out.
\end{abstract}

Keywords: Multiple Sclerosis; Prevalence; Epidemiology.

\begin{abstract}
RESUMO
Introdução: Para melhor comparar a prevalência de esclerose múltipla (EM) nas diferentes regiões do Brasil, o Comitê Brasileiro para Tratamento e Pesquisa em Esclerose Múltipla implementou uma abordagem padronizada para avaliar a prevalência da doença em 5 cidades-chave, consideradas representativas de suas regiões em termos de características sociogeográficas e nas quais seria viável revisar cada caso pessoalmente. Objetivos: Descrever a prevalência pontual de EM em Passo Fundo, uma das cidades-chave, localizada no Sul do Brasil. Métodos: Buscamos identificar todos os pacientes com EM que viviam em Passo Fundo no dia $1^{\circ}$ de julho de 2015 . A fonte primária para identificação de casos foi os registros de consultórios de neurologistas e neurocirurgiões da cidade. Múltiplas fontes secundárias foram usadas para maximizar a identificação de casos. Todos os pacientes tiveram o diagnóstico revisado pessoalmente por um painel de neurologistas com experiência em EM. Resultados: Identificamos 52 pacientes com EM que viviam em Passo Fundo em $1^{\circ}$ de julho de 2015. Assim, a prevalência pontual bruta de EM foi 26,4/100.000 habitantes (intervalo de confiança de 95\%, 19,7 a 34,6/100.000). Entre os casos de EM, 42 (80,8\%) eram mulheres, (razão de sexos: 4,2:1). Quarenta e seis casos (88,5\%) foram categorizados como EM remitente-recorrente, e os 6 casos restantes como EM secundariamente progressiva (11,5\%). As demais características epidemiológicas e clínicas foram comparáveis a populações de EM internacionais. Conclusões: A prevalência de EM em Passo Fundo é uma das maiores já relatadas no Brasil. Estudos em outras cidades-chave brasileiras, usando a mesma metodologia, estão em andamento.
\end{abstract}

Palavras-chave: Esclerose Múltipla; Prevalência; Epidemiologia.

${ }^{1}$ Pontifícia Universidade Católica do Rio Grande do Sul, Hospital São Lucas, Porto Alegre RS, Brazil.

${ }^{2}$ Hospital de Clínicas de Passo Fundo, Serviço de Neurologia e Neurocirurgia, Passo Fundo RS, Brazil.

${ }^{3}$ Hospital São Vicente de Paulo, Passo Fundo RS, Brazil.

¿Universidade Federal de São Paulo, Faculdade de Medicina, Hospital das Clínicas, São Paulo SP, Brazil.

${ }_{5}^{5}$ Universidade Federal de Minas Gerais, Centro de Investigação em Esclerose Múltipla de Minas Gerais, Belo Horizonte MG, Brazil.

GRP (DD https://orcid.org/0000-0002-8949-6115;JB (DD https://orcid.org/0000-0002-9981-3620; DLV (D) https://orcid.org/0000-0002-3043-1640; ACF (D) https://orcid.org/0000-0003-1932-7452; BCR (D) https://orcid.org/0000-0003-0863-8917; ACSM (iD) https://orcid.org/0000-0002-0523-5090;

DC (1D https://orcid.org/0000-0003-0077-173X; Marco A. Lana-Peixoto (i) https://orcid.org/0000-0003-2454-681X

Correspondence: Marco A. Lana-Peixoto; Email:marco.lanapeixoto@gmail.com.

Support: This study has been funded by the Brazilian Committee for Treatment and Research in Multiple Sclerosis, and Novartis Biociências S.A.

Conflict of interest: There is no conflict of interest to declare.

Authors' contributions: JB, DLV, DC, MALP: study conception and design; GRP, JB, DLV, ACF, BCR, ACSM, DC, MALP: data collection; GRP, JB, DC, MALP: data interpretation and analyses; GRP, JB, DC, MALP: manuscript writing; GRP, JB, DLV, ACF, BCR, ACSM, DC, MALP: final approval of the manuscript.

Received on May 19, 2020; Received in its final form on September 12, 2020; Accepted on September 30, 2020. 


\section{INTRODUCTION}

The prevalence of multiple sclerosis (MS) reported in Brazil varies widely across regions ${ }^{1}$, which may be due to genetic and environmental diversity as well as to methodological differences across studies. To improve comparability, the Brazilian Committee for Treatment and Research in Multiple Sclerosis (BCTRIMS) has implemented a standardized approach to assess the prevalence of MS in five key cities, which were deemed representative of their regions in terms of socio-geographical features and where personal revision of each case was feasible. The rationale, purposes, and general methods of this initiative are described elsewhere ${ }^{2}$. In the present study, we aimed to report the point prevalence of MS on July $1^{\text {st }}, 2015$ in Passo Fundo, one of the key cities, which is located in Rio Grande do Sul state, Southern Brazil.

\section{METHODS}

In order to identify all patients living in Passo Fundo with an established diagnosis of MS on the prevalence day (July $1^{\text {st }}$, 2015), we invited all adult and pediatric neurologists and neurosurgeons who were practicing in the city to provide data regarding MS cases under their care, as a primary source for case ascertainment. Secondary sources included the database of the Municipal Department of Health, which provides disease-modifying therapies for nearly all MS patients, the membership list of the local MS patient association, and advertisements on radio and television so that MS patients could self-refer to the research team. The present study received ethics approval from the Research Ethics Committee of Federal University of Minas Gerais (study number 666650).

Case ascertainment took place between October and December 2015, using the strategy shown in Figure 1. Patients ascertained from different sources were considered overlaps if they had identical names. All potential cases were reviewed in-person on December $12^{\text {th }} 2015$ by a panel of neurologists with experience in MS (ACF, BCR, DLV, JB, and MALP). The assessment included demographic data, history of MS, neurological examination, and results of magnetic resonance imaging (MRI), cerebrospinal fluid examination, and other paraclinical tests. MS was diagnosed according to the modified McDonald criteria (2010) ${ }^{3}$ and categorized according to the phenotypes proposed by Lublin et al, modified in $2013^{4}$. We did not aim to include patients with clinically isolated syndromes (CIS). Disability was assessed by means of the Expanded Disability Status Scale (EDSS) ${ }^{5}$.

Cases in which the diagnosis of MS could not be confirmed by the examining panel and MS patients whose diagnosis had been established after July $1^{\text {st }}, 2015$ were discarded. Patients who were alive on July $1^{\text {st }}, 2015$ and deceased afterwards, before the study date, were included, provided there was consistent evidence supporting the diagnosis of MS.

An official estimate for the Passo Fundo population size in 2015 was obtained from the Brazilian Institute of Geography and Statistics (IBGE) ${ }^{6}$. Further information on the composition of the local population, such as age, gender, and ethnic

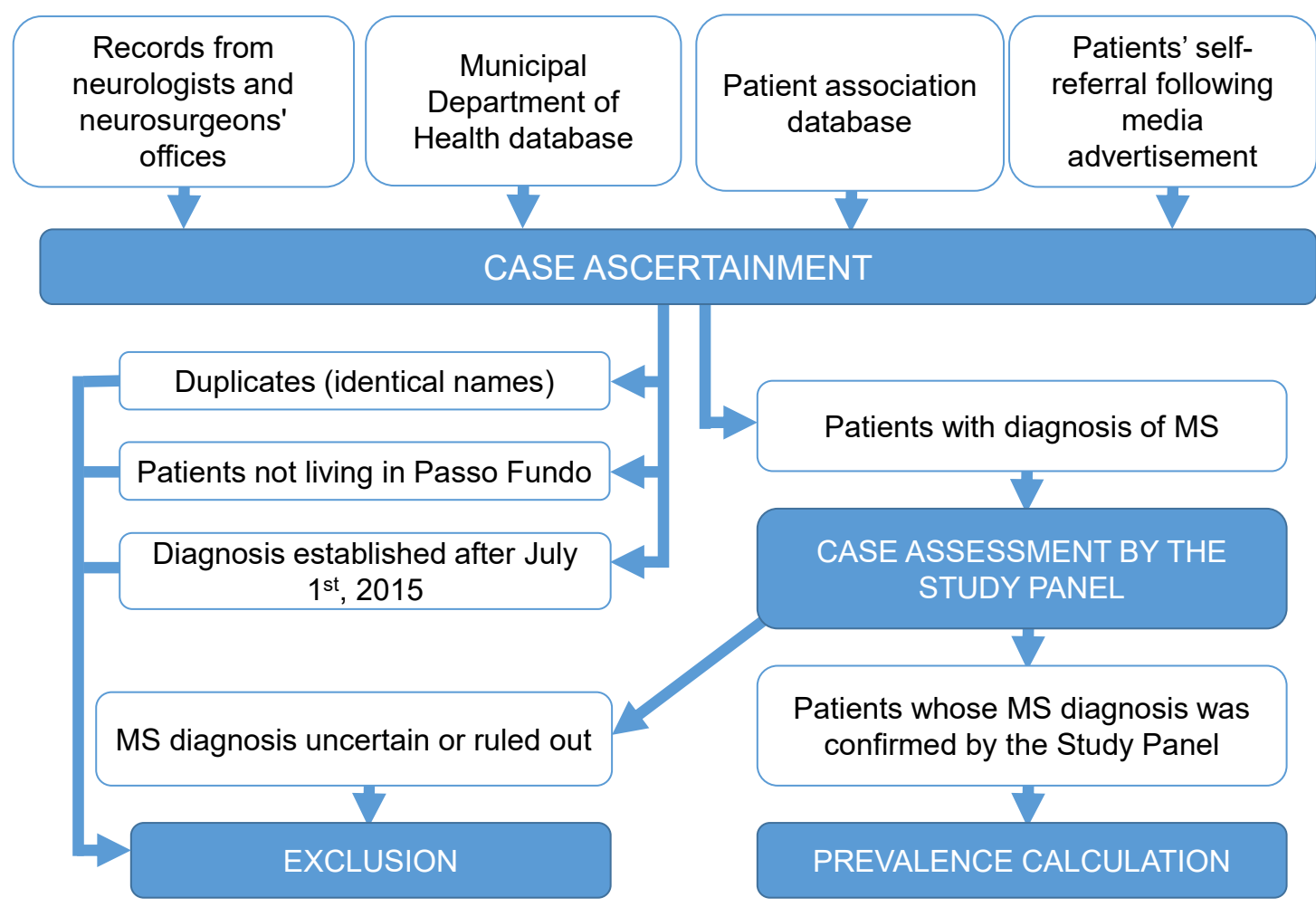

Figure 1. Case ascertainment in the multiple sclerosis prevalence study in Passo Fundo. 
distribution, was only available from IBGE's 2010 census (the latest), and not for the year $2015^{7}$. Similarly, the latest survey of healthcare resources, also from the IBGE, dated back from $2009^{8}$. Geographical and socioeconomic information about Passo Fundo was collected from an online atlas?.

We calculated the point-prevalence rate for July $1^{\text {st }}, 2015$ and estimated the $95 \%$ confidence intervals (95\% CI) with the method proposed by Schoenberg ${ }^{10}$. Reporting of the present study was done in accordance to the Standards of Reporting of Neurological Disorders (STROND) guidelines - Application to $\mathrm{MS}^{11}$.

\section{RESULTS}

\section{Area and population}

Passo Fundo is located at $28^{\circ} 15^{\prime}$ South latitude and $52^{\circ}$ 24 ' West longitude (Figure 2), 680 meters above sea level ${ }^{9}$. The climate is humid subtropical (Köppen climate classification: $\mathrm{Cfa})^{9}$. Both urban and rural environments are comprised in a total area of 783,421 square kilometers 9 .

The population of Passo Fundo on July $1^{\text {st }}, 2015$ was $196,739^{6}$. Based on data from the 2010 census, $97 \%$ of the people lived in the urban area, and the majoritarian ethnic groups were Caucasian (83\%) and mixed ancestry $(14 \%)^{8}$. The latter comprises mostly individuals of mixed Caucasian and African ancestry. The Municipal Human Development Index (MHDI), also from 2010, was 0.776 (classified as high) ${ }^{8}$.

In 2009, there were 86 outpatient facilities (including public clinics and private practices), 7 inpatient care facilities (totaling 974 beds), and 8 MRI scanners ${ }^{8}$. As of 2015, there were 24 adult and pediatric neurologists and neurosurgeons practicing in the city (unpublished data). Universal medical insurance coverage was available for all residents in Passo Fundo, by means of the Brazilian public healthcare system and/or private insurance companies.

\section{Case ascertainment and assessment}

Among the 24 adult and pediatric neurologists and neurosurgeons practicing in Passo Fundo at the study date, only one declined the invitation to collaborate with case ascertainment.

Fifty-two potential MS cases were identified, after exclusion of duplicates, subjects not living in Passo Fundo, and patients whose diagnosis of MS had been established after the prevalence day. All patients were alive on the study date and were contacted by the study team. All patients were able to attend the in-person review of diagnosis.

\section{Prevalence}

We identified $52 \mathrm{MS}$ patients who were living in the city of Passo Fundo on July $1^{\text {st }}, 2015$, which yielded a point-prevalence of $26.4 / 100,000$ population (95\% CI, 19.7 to $34.6 / 100,000$ ).

\section{Epidemiological and clinical features}

Epidemiological and clinical features of the MS patients living in Passo Fundo on the prevalence day are described in Table 1. Among the 52 MS cases, $42(80.8 \%)$ were female, for a sex ratio of 4.2:1. The median age on the prevalence day was 40 years (range, 19 to 76 years). Regarding ethnicity, there were 51 (98.1\%) Caucasians and 1 (1.9\%) mixed ancestry individual (Caucasian/African).

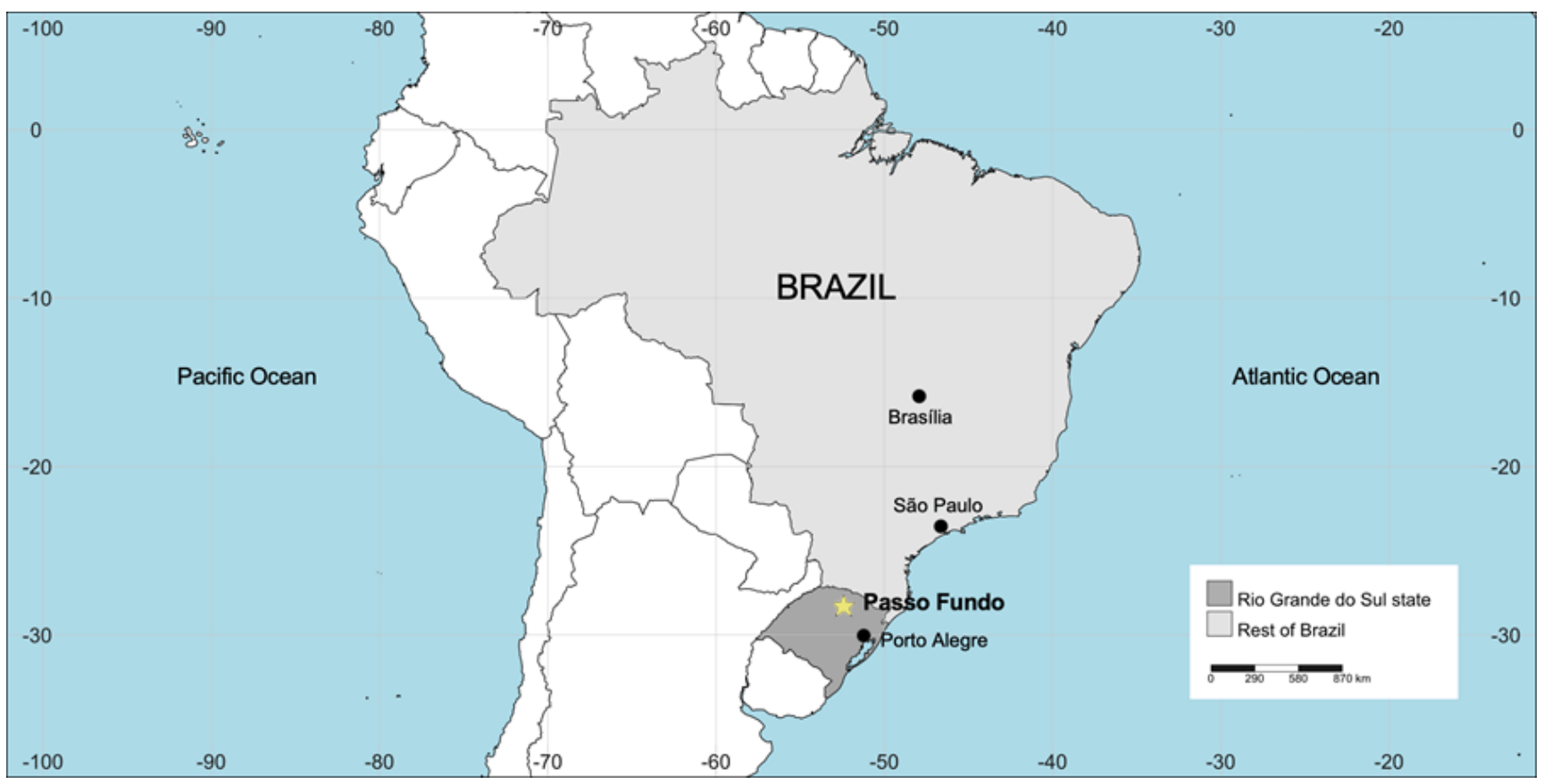

Map created using SimpleMappr ${ }^{\oplus}$, available at https://www.simplemappr.net.

Figure 2. Location of Passo Fundo, in Rio Grande do Sul state, Southern Brazil. 
Table 1. Epidemiological and clinical features of MS patients living in Passo Fundo on the prevalence day (July 1 ${ }^{\text {st }}, 2015$ ).

\begin{tabular}{|c|c|}
\hline & MS cases $(n=52)$ \\
\hline \multicolumn{2}{|c|}{ Gender } \\
\hline Female & $42(80.8 \%)$ \\
\hline Male & $10(19.2 \%)$ \\
\hline \multicolumn{2}{|c|}{ Age at prevalence day } \\
\hline Median & 40 years \\
\hline Range & $19-76$ years \\
\hline \multicolumn{2}{|c|}{ Ethnicity } \\
\hline Caucasian & $51(98.1 \%)$ \\
\hline Brown & $1(1.9 \%)$ \\
\hline \multicolumn{2}{|c|}{ Age at MS onset } \\
\hline Median & 34.5 years \\
\hline Range & $14-66$ years \\
\hline \multicolumn{2}{|c|}{ MS phenotype } \\
\hline Relapsing-remitting & $46(88.5 \%)$ \\
\hline Secondary progressive & $6(11.5 \%)$ \\
\hline \multicolumn{2}{|c|}{ EDSS score } \\
\hline Median (range) & $2.0(0-9.5)$ \\
\hline \multicolumn{2}{|c|}{ Current DMT } \\
\hline Fingolimod & $13(25.0 \%)$ \\
\hline Glatiramer acetate & $2(3.8 \%)$ \\
\hline Interferon beta-1a, IM & $16(30.8 \%)$ \\
\hline Interferon beta-1a, SC & $1(1.9 \%)$ \\
\hline Interferon beta-1b & $3(5.8 \%)$ \\
\hline Natalizumab & $6(11.5 \%)$ \\
\hline None & $11(21.2 \%)$ \\
\hline
\end{tabular}

DMD: disease-modifying therapy; EDSS: Expanded Disability Status Scale; IM: intramuscular; MS: multiple sclerosis; SC: subcutaneous.

Forty-six cases $(88.5 \%)$ were categorized as relapsingremitting MS, and the remaining 6 cases as secondary progressive MS (11.5\%). No patients with primary progressive MS were identified in Passo Fundo on the prevalence day.

The median age at disease onset was 34.5 years (range, 14 to 66 years). In 4 (7.7\%) out of the 52 patients, the onset had been before the age of 18 years. Information on EDSS was available for 49 patients: the median score was 2.0 (range, 0.0 to 9.5). Sixteen patients (30.8\%) were receiving intramuscular interferon beta-1a, 13 (25.0\%) fingolimod, 6 (11.5\%) natalizumab, 6 (11.5\%) other disease-modifying therapies, and 11 (21.2\%) were off treatment.

\section{DISCUSSION}

We found that the prevalence rate of MS in Passo Fundo is 26.4 cases per 100,000 population. To our knowledge, there are no previous estimates of MS prevalence in this city. However, this rate is comparable to that of Santa Maria, a city with similar socio-demographic features, located around 200 kilometers far from Passo Fundo, where the prevalence rate of MS was reported at 27.2 per 100,000 population ${ }^{12}$. No other studies reporting MS prevalence rates in Rio Grande do Sul state were found.

We selected Passo Fundo as a key city for prevalence study in Brazil due to several reasons. First of all, it can be assumed that its population is representative of the general population of Rio Grande do Sul state, both in terms of ethnic/genetic background and environmental exposures. In addition, the health resources available locally are good and have rendered Passo Fundo a reference in Neurology for many neighboring cities. On the other hand, the population size under 200,000 maximizes the chance of ascertaining and personally reviewing all MS cases.

The possibility for under-ascertainment of cases is the main limitation of this study. The main reason would be the delay between the initial symptoms of MS and establishing a formal diagnosis, which can take several months or years, either because of criteria-related issues (some patients are initially diagnosed with CIS, which we have not included in our study, some simply do not fulfill the criteria for either CIS or MS) or due to healthcare-related issues (e.g. delays in suspecting the diagnosis in the primary care setting, referring for specialized consultation, or completing the diagnostic workup).

Additionally, some patients may have been missed if they were not on regular follow-up and/or treatment, were followed-up only by general practitioners or specialists other than neurologists and neurosurgeons, were followed-up in other cities despite living in Passo Fundo, and/or were getting their medications from a source other than the public health system. However, the chances of missing MS patients were minimized by the use of multiple health system-based data sources, in addition to community-targeted strategies such as media advertisements.

On the other hand, it might be speculated that some people with significant MS-related disability originally living in smaller, neighboring cities eventually end up moving to Passo Fundo due to the greater availability of health resources, which could lead to some degree of prevalence overestimation, but likely not enough to overcome the previously mentioned underestimating factors. Therefore, we believe that the prevalence rate reported in the present study should be regarded as the minimal prevalence of MS in the city.

Yet, the prevalence of MS in Passo Fundo is among the highest reported in Brazil so far. A systematic review of studies investigating the prevalence of MS in several Brazilian cities found rates between 1.4 (in Recife, Northeast Brazil) and 27.2 per 100,000 population (in Santa Maria, Southern Brazil), with $80 \%$ of the studies reporting rates between 4.3 and 18.1 per 100,000 population ${ }^{1}$. In line with the study from Santa Maria, the present study corroborates that Rio Grande do Sul, 
the southernmost state in Brazil, has the highest prevalence of MS in the country, which could be due to genetic and environmental factors.

Studies on the interethnic admixture of the Rio Grande do Sul population have reported genetic contributions mainly from Europeans (63-94\%), in whom MS is far more prevalent, versus only 4-30\% from Amerindians and 2-7\% from Africans ${ }^{13,14}$, whereas the genetic contributions of the latter groups are higher in most of the other Brazilian states. The positive association between latitude and MS prevalence may also account for the higher prevalence in Passo Fundo (and Rio Grande do Sul state as well) in comparison to other Brazilian regions, especially because such association is particularly relevant for populations of European descent ${ }^{15,16}$.

Interestingly, the MS female-to-male ratio of 4.2:1 in Passo Fundo exceeds that reported for the neighboring city of Santa Maria $(2.7: 1)^{12}$ and for the Americas as a whole $(2.6: 1)^{17}$. This excess is unlikely to result from unbalanced gender distribution in the general population across these areas, since the proportion of females in Passo Fundo (52.4\%) is similar to that of Santa Maria (52.6\%) and Brazil as a whole (51.0\%), based on the 2010 census $^{7}$. Median age at MS onset, distribution of phenotypes and proportion of pediatric cases in Passo Fundo are roughly similar to national ${ }^{18}$ and international data ${ }^{17}$.

Unfortunately, we were not able to provide exact age-, sexand ethnic group-adjusted prevalence rates, which would facilitate subsequent comparability between cities, as the data required for these analyses (age, sex and ethnic group composition of the Passo Fundo population in 2015) are not available in IBGE information systems.

In conclusion, this study shows that the prevalence rate of MS in Passo Fundo, Southern Brazil on July $1^{\text {st }}$, 2015 was 26.4 per 100,000 population and corroborates that Rio Grande do Sul, the southernmost state in Brazil, has the highest prevalence of MS in the country. Studies in other Brazilian key cities, using the same methodology to ensure comparability of prevalence rates across different regions of the country, are currently being carried out.

\section{REFERENCES}

1. da Gama Pereira ABCN, Lacativa MCS, da Costa Pereira FFC Alvarenga RMP. Prevalence of multiple sclerosis in Brazil: a systematic review. Mult Scler Relat Disord. 2015 Nov 1;4(6):572-9. https://doi.org/10.1016/j.msard.2015.08.004

2. Gonçalves MVM, Siquineli F, Ribas FD, Longo AL, do Amaral CH, Chikota EM, et al. Prevalence of multiple sclerosis in key cities of brazil. A study in Joinville, Southern Brazil. Arq Neuropsiquiatr. 2021 Feb;79(2):122-6. https://doi.org/10.1590/0004-282X-anp-2020-0101

3. Polman CH, Reingold SC, Banwell B, Clanet M, Cohen JA, Filippi M, et al. Diagnostic criteria for multiple sclerosis: 2010 Revisions to the McDonald criteria. Ann Neurol. 2011 Feb;69(2):292-302. https://doi. org/10.1002/ana.22366

4. Lublin FD, Reingold SC, Cohen JA, Cutter GR, Sørensen PS, Thompson AJ, et al. Defining the clinical course of multiple sclerosis: the 2013 revisions. Neurology. 2014 Jul 15;83(3):278-86. https://doi. org/10.1212/WNL.0000000000000560

5. Kurtzke JF. Rating neurologic impairment in multiple sclerosis: an expanded disability status scale (EDSS). Neurology. 1983 Nov;33(11):1444-52. https://doi.org/10.1212/WNL.33.11.1444

6. IBGE [Internet]. Estimativas da população residente no Brasil e unidades da Federação com data de referência em $1^{\circ}$ de Julho de 2015. Brasil: Instituto Brasileiro de Geografia e Estatística; 2015. [cited $2020 \mathrm{Jul}$ 29]. Available from: https://www.ibge.gov.br/ estatisticas/sociais/populacao/9103-estimativas-de-populacao. $\mathrm{htm}$ ? edicao $=17283 \& \mathrm{t}=$ downloads

7. IBGE [Internet]. Censo Demográfico 2010. Brasil: Instituto Brasileiro de Geografia e Estatística; 2010. [cited 2020 Jul 29]. Available from: https://cidades.ibge.gov.br/brasil/pesquisa/23/25888?detalhes=true

8. IBGE [Internet]. Cidades - Passo Fundo. Brasil: Instituto Brasileiro de Geografia e Estatística; 2010. [cited 2017 Apr 20]. Available from: http://cidades.ibge.gov.br/xtras/perfil.php?lang $=\&$ codmun $=431410$ \&search=rio-grande-do-sul

9. DB-city.com [Internet]. Passo Fundo. 2016. [cited 2017 Apr 20]. Available from: http://pt.db-city.com/Brasil--Rio-Grande-do-Sul-Passo-Fundo
10. Schoenberg BS. Calculating confidence intervals for rates and ratios. Neuroepidemiology. 1983;2:257-65. https://doi. org/10.1159/000110529

11. Fiest KM, Marrie RA, Jette N, Bennett DA. The Standards of Reporting of Neurological Disorders (STROND) checklist: application to multiple sclerosis. Mult Scler. 2017 Jan;23(1):23-33. https://doi. org/10.1177/1352458516634873

12. Finkelsztejn A, Lopes JS, Noal J, Finkelsztejn JM. The prevalence of multiple sclerosis in Santa Maria, Rio Grande do Sul, Brazil. Arq Neuropsiquiatr. 2014 Feb;72(2):104-6. https://doi.org/10.1590/0004$282 \times 20130216$

13. Dornelles CL, Callegari-Jacques SM, Robinson WM, Weimer TA, Franco MHLP, Hickmann AC, et al. Genetics, surnames, grandparents' nationalities, and ethnic admixture in Southern Brazil: Do the patterns of variation coincide? Genet Mol Biol. 1999 Jun;22(2):151-61. https://doi.org/10.1590/S1415-47571999000200003

14. Marrero AR. História genética dos gaúchos: dinâmica populacional do Sul do Brasil [Tese de Doutorado]. [Porto Alegre (RS)]: Universidade Federal do Rio Grande do Sul; 2006. 223p.

15. Simpson Jr S, Blizzard L, Otahal P, Van der Mei I, Taylor B. Latitude is significantly associated with the prevalence of multiple sclerosis: a meta-analysis. J Neurol Neurosurg Psychiatry. 2011 Oct;82(10):113241. https://doi.org/10.1136/jnnp.2011.240432

16. Comini-Frota ER, Brum DG, Kaimen-Maciel DR, Fragoso YD, Barreira AA, Donadi EA. Frequency of reported European ancestry among multiple sclerosis patients from four cities in the southern and southeastern regions of Brazil. Clin Neurol Neurosurg. 2013 Sep;115(9):1642-6. https://doi.org/10.1016/j.clineuro.2013.02.024

17. Multiple Sclerosis International Federation. Atlas of MS 2013: Mapping Multiple Sclerosis Around the World. Multiple Sclerosis International Federation; 2013.

18. Vasconcelos CCF, Thuler LCS, Rodrigues BC, Calmon AB, Alvarenga RMP. Multiple sclerosis in Brazil: a systematic review. Clin Neurol Neurosurg. 2016 Dec;151:24-30. https://doi.org/10.1016/j. clineuro.2016.07.011 